\title{
Nooren et al., Explosive eruption of El Chichón volcano (Mexico) disrupted 6th century Maya civilization and contributed to global cooling
}

\section{Tephrostratigraphical framework}

In absence of a comprehensive regional tephrostatigraphical framework for the Maya Lowlands, we derived a chronological record of El Chichón's eruptive activity from multiple sediment cores taken in the floodbasin of the Usumacinta-Grijalva delta. The PP1 core, obtained in 2001 with a Russian peat sampler, was investigated in detail for the presence of (crypto-) tephra and its potential sources at Utrecht University. For the construction of an age-depth model a total of twenty core samples were radiocarbon dated. Terrestrial macro-remains were isolated from the core material, pretreated by standard AAA and ${ }^{14} \mathrm{C}$ dated at the Groningen AMS facility (Van der Plicht et al., 2000). The ${ }^{14} \mathrm{C}$ ages are reported in yr BP (Table S1), which includes correction for isotopic fractionation using ${ }^{13} \mathrm{C}$ and the Libby half-life (Mook and Van der Plicht, 1999). All radiocarbon ages were calibrated with the software package OxCal 4.2 (Bronk Ramsey, 2009) using the recommended IntCal13 calibration curve (Reimer et al., 2013). The probability distribution of the calibrated ages is shown in Figure S1 and S2.

Volcanic glass shards and pumice particles were isolated from the sediments at 1-cm intervals conform the method of Blockley et al. (2005). Major-element composition of the glass shards was determined on 2-12 particles per sample with a Jeol JXA 8600 microprobe, equipped with 5 wavelength dispersive spectrometers. Measurements were performed by WDS using $15 \mathrm{kV}$ acceleration voltage, $10 \mathrm{nA}$ beam current and a defocused beam ( $5 \mu \mathrm{m}$ spot size) to minimize mobilization of sodium. Instrumental performance and calibration were monitored by repeated analysis of natural glass standards (rhyolitic USNM 72854 VG-568 and basaltic USNM 111240 VG-2) and in-house mineral standards. A sample from the Tierra Blanca Joven (TBJ) tephra of Ilopango volcano was measured for comparison.

The composition of glass shards and pumice glass of all analyzed samples is rhyolitic (Table S2). They can be subdivided into three clusters as illustrated in the $\mathrm{SiO}_{2}-\mathrm{CaO}$ and $\mathrm{Al}_{2} \mathrm{O}_{3}$ - $\mathrm{K}_{2} \mathrm{O}$ diagrams (Fig. S3). Comparison with compositions of tephra glass from volcanoes in the region (Fig. S3) points to El Chichón as tephra source for clusters 1 and 2. Cluster 1 falls in the field defined by glass from El Chichón's last two eruptions (Cochemé and Silva-Mora, 1983; Devine et al., 1984; Luhr et al., 1984; Palais et al., 1992; Macías et al., 2003), corresponding to units $\mathrm{A}$ and $\mathrm{B}$, whereas cluster 2 represents a slightly more evolved variety.

The $540 \mathrm{CE}$ tephra layer in the floodbasin cores has a bimodal grain-size distribution, indicating that it consists of a mixture of two components. Glass shards of the dominating $(\sim 70 \mathrm{w} \%)$ silt-size $(2-53 \mu \mathrm{m})$ mode have a cluster 2 composition. We interpret this component as tephra fall from El Chichón, originating from more evolved magma relative to cluster 1, which covers the majority of tephra glass compositions produced by the volcano. Cluster 2 glass is also present in an older tephra in PP1, which is taken to be equivalent to Unit H (Espíndola et al., 2000) (Fig. S2). 
The overall compositional variation of the glasses and the difference between the two clusters is small, in line with the observation that bulk chemical compositions of El Chichón's erupted products have remained fairly constant over the past 3100 years (Andrews et al., 2008). Nevertheless, the shift towards slightly less siliceous glass (from cluster 2 to cluster 1 ) is meaningful, and is consistent with a major recharge of mafic magma before the ca. $900 \mathrm{cal}$. $\mathrm{yr}$ B.P. eruption (represented by Unit C), inferred from rock and mineral compositional variations in proximal products (Jones et al., 2008).

Glass from relatively large, sand-size pumice particles $(53-300 \mu \mathrm{m}$, median $85 \mu \mathrm{m})$ in the $540 \mathrm{CE}$ tephra layer has a cluster-3 composition, equivalent to a siliceous rhyolite (Fig. S3, Table $\mathrm{S} 2$ ). Since no such composition is known from El Chichón and similar cluster-3 material is also present in other levels of the PP1 core, we infer that it represents re-worked products from a different volcano. The major-element composition is close to that of the Los Chocoyos tephra from the caldera-forming Atitlán eruption in Guatemala around 84,000 years ago (Kutterolf et al. 2008), which is arguably the largest Quaternary silicic pyroclastic unit in Central America (e.g. Drexler et al., 1980). It is therefore likely that cluster-3 represents eroded Los Chocoyos pumice, present in the drainage basin of the Grijalva and Usumacinta rivers. Reworked sediments from those older deposits were likely introduced into the flood-basins of the delta during large flood events.

According to the more comprehensive tephrostratigraphic framework available now, we infer that the relatively coarse-grained particles in the equivalent tephra layer of the Pozpetr core, originally attributed to an El Chichón eruption (Nooren et al., 2009), are part of cluster 3 and thus represent similar re-worked material. Finally, we note that none of the glass compositions matches that of the TBJ tephra from a 5- $6^{\text {th }}$ century eruption of Ilopango in El Salvador (Dull et al., 2001) (Table S2, Fig. S3).

\section{FIGURES}

Figure S1 (page 3). Probability distribution of calibrated ages for available radiocarbon dated samples from proximal (A) and distal (B) deposits of El Chichón volcano (grey), and intercalated palaeosoils (light grey) (Tilling et al., 1984; Espíndola et al., 2000). The ages of thick pumice flow and surge deposits of 'unit D' (Tilling et al., 1984), block and ash flow deposits of unit E (Espíndola et al., 2000), as well as distal tephra deposits in flood-basin cores PP1 and Pozpetr (Nooren et al., 2009) coincide with the 540 CE event recorded in bipolar ice cores (cf. Fig. S2). Note that letter coding for the proximal stratigraphic units in the upper part of panel A (Tilling et al., 1984, reproduced with permission) differs from that in the lower part that follows a later study (Espíndola et al., 2000) in which more eruptive events were reported.

Figure S2 (page 4). Age-depth model and tephrostratigraphy of the PP1 core (Usumacinta-Grijalva delta flood-basin, location in Fig. S1). Four (crypto-) tephra layers are correlated to El Chichón's proximal deposit units A, B, E and H (Espíndola et al., 2000). Vertical lines connect the six largest bipolar volcanic sulfate peaks in the bar graphs for NEEM-2011-S1 and WDC06A ice cores, indicating estimated volcanic sulfate deposition in Greenland (blue) and Antarctica (red), respectively (Sigl et al., 2015). Horizontal lines indicate 12 levels from which isolated volcanic glass was analyzed. Total clastics (\% of fresh weight) are represented as two fractions for samples taken at 0-63 cm depth $\left(2.0-2.5 \mathrm{~g} / \mathrm{cm}^{3}\right.$ in purple; $>$ $2.5 \mathrm{~g} / \mathrm{cm}^{3}$ in grey) and for samples taken at $63-88 \mathrm{~cm}\left(2.0-2.3 \mathrm{~g} / \mathrm{cm}^{3}\right.$ in red; $>2.3 \mathrm{~g} / \mathrm{cm}^{3}$ in grey). Volcanic glass has a density between 2.0 and $2.5 \mathrm{~g} / \mathrm{cm}^{3}$. 


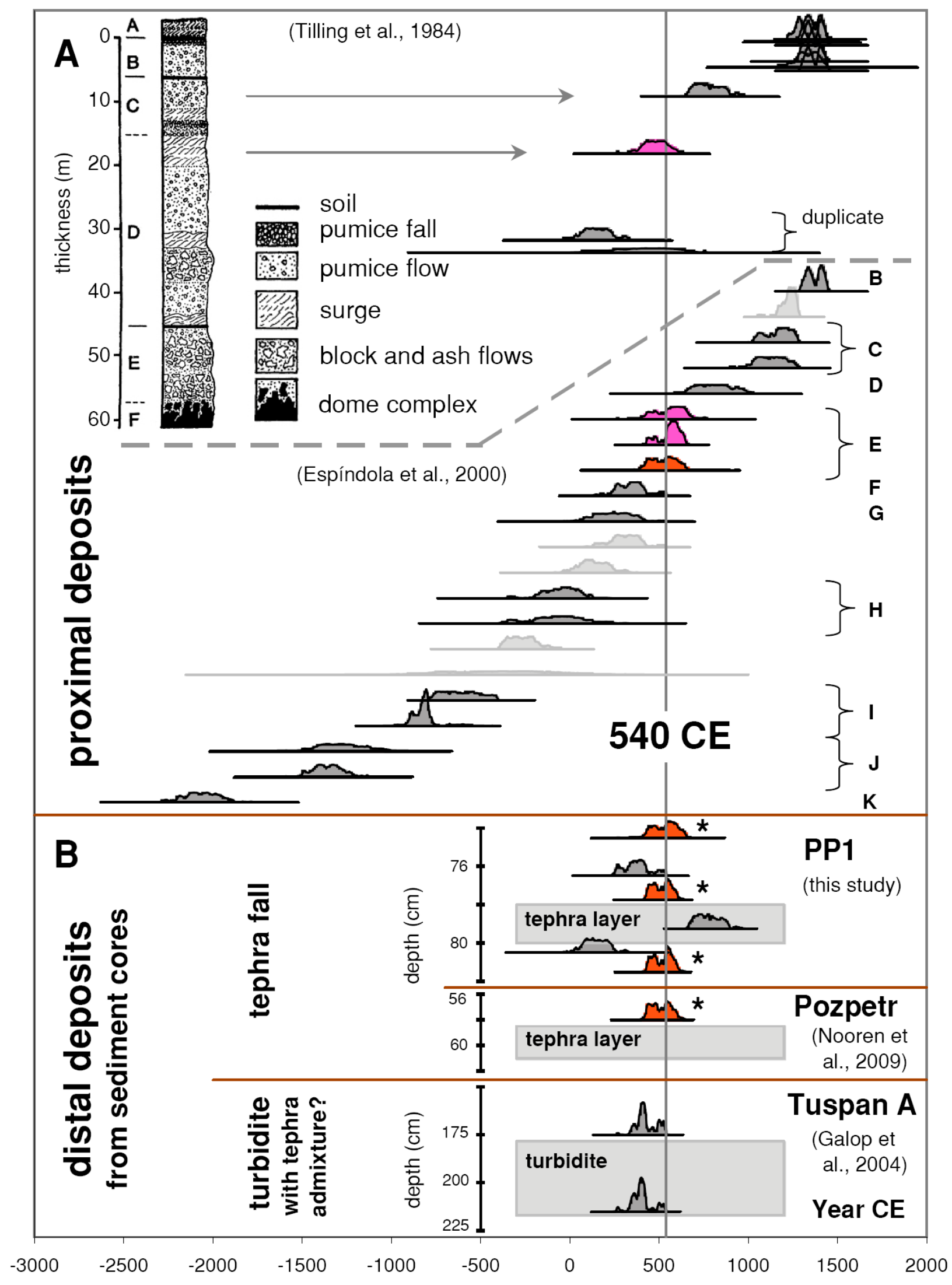




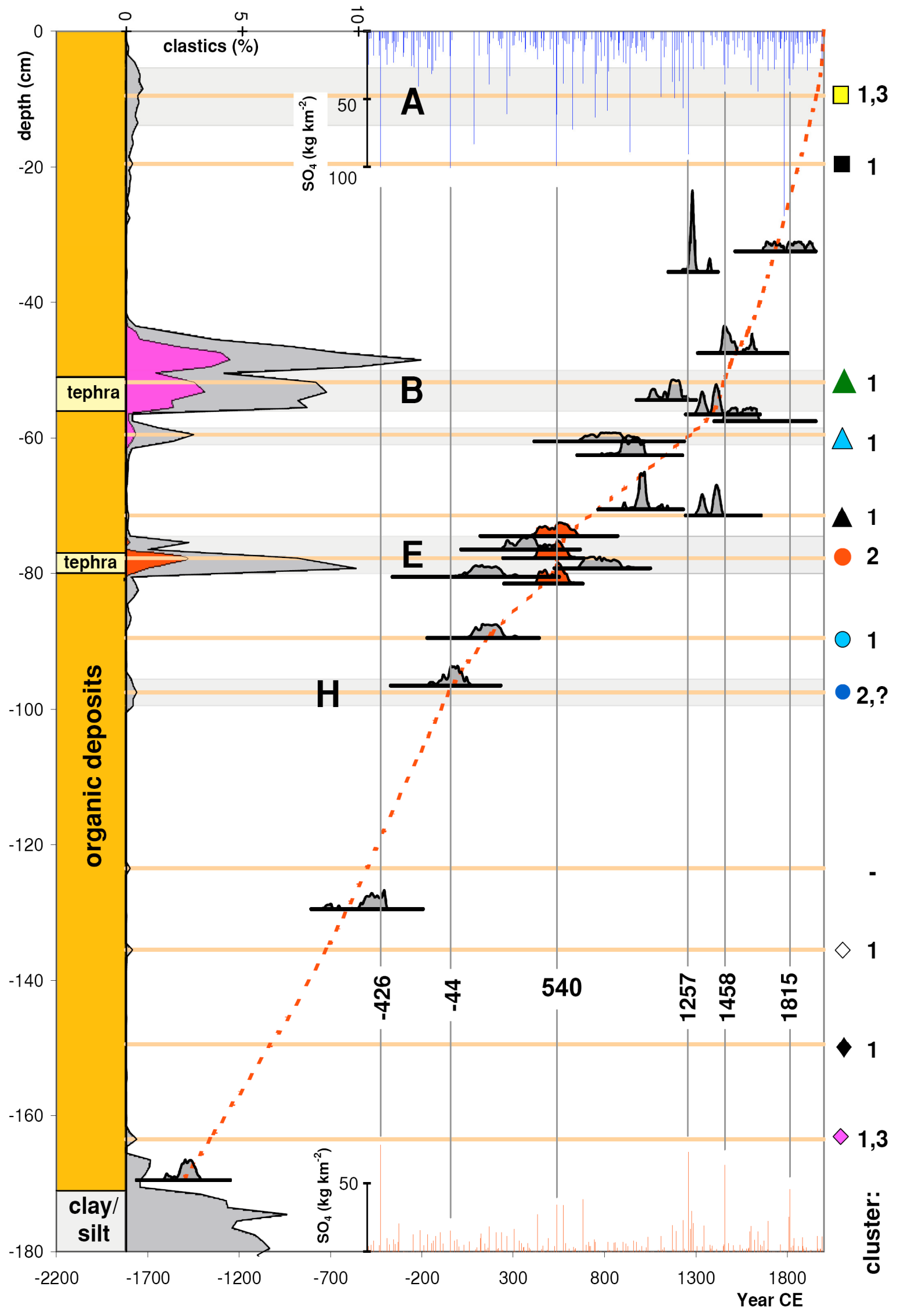



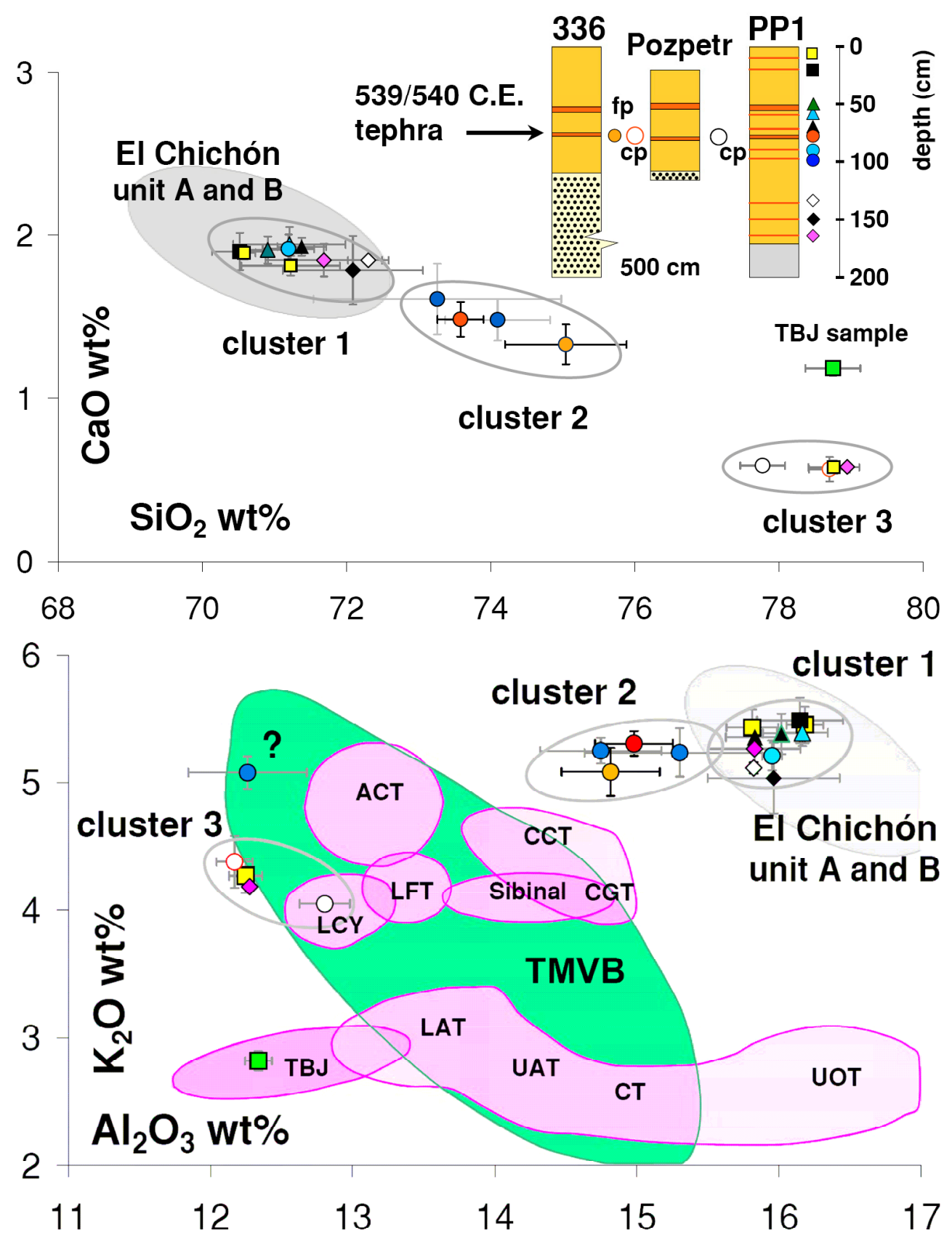

Figure S3. Major-element compositions of analyzed tephra glass from flood-basin cores in comparison to glass from El Chichón's 1982 tephra (Cochemé and Silva-Mora, 1983; Devine et al, 1984; Luhr et al., 1984), El Chichón's unit B (Palaís et al., 1992; Macías et al, 2003), Tacana’s Sibinal tephra (Arce et al., 2012), TMVB tephras (green) (Ortega-Guerrero and Newton, 1998) and various CAVA tephras (purple) (Kutterolf et al., 2008) including Los Chocoyos tephra (LCY). Data points represent averages for 2-12 particles (bars are $1 \sigma$ ). Symbols not explained in the legend correspond to the (crypto-) tephra layers of the PP1 core (see Fig. S2). $\mathrm{fp}=$ fine particles, $\mathrm{cp}=$ course particles. We identified the 540 C.E tephra in core 336 through stratigraphic correlation with the Pozpetr (Nooren et al., 2009) and PP1 cores. 


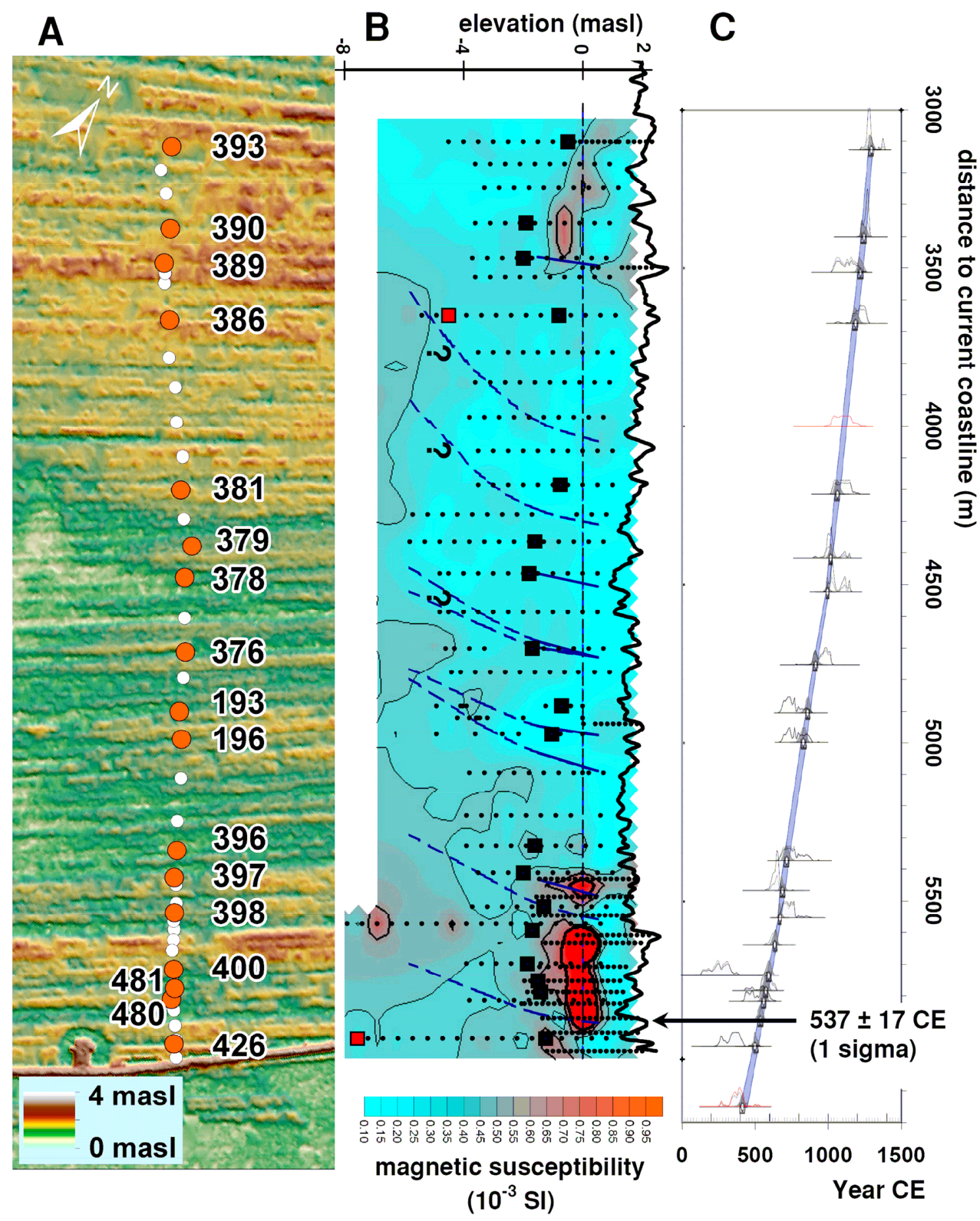

Figure S4. A: Transect A2 across beach ridge sand with sample locations. $B$ : Magnetic susceptibility results. Black squares indicate the AMS ${ }^{14} \mathrm{C}$ dated organic debris layers. $C$ : Bayesian model results for all

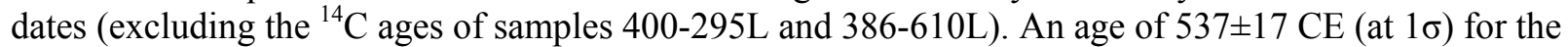
sudden increase in magnetic susceptibility, inferred to reflect a supply of magnetite from the mid- $6^{\text {th }}$ century eruption of El Chichón. The age-distance model was constructed using a depositional $\mathrm{P}$ sequence model $(\mathrm{k}=0.05)$ of the Oxcal 4.2 calibration program (Bronk Ramsey, 2009) using the IntCal13 calibration curve (Reimer et al., 2013) and an estimated shoreface slope of $4^{\circ}$. The digital elevation model in $A$ is based on Lidar data from 2007, generously provided by INEGI, Mexico. 


\section{TABLES}

Table S1. AMS 14C dated samples.

\begin{tabular}{|c|c|c|c|c|c|c|}
\hline $\begin{array}{l}\text { Sample } \\
\text { code }\end{array}$ & $\begin{array}{c}\text { Estimated } \\
\text { time after } \\
\text { eruption } \\
(y r))^{1)}\end{array}$ & 2) & GrA & Age BP & $1 \sigma$ & Extracted fraction \\
\hline \multicolumn{7}{|c|}{ pyroclastic flow deposits 3 ) } \\
\hline $\mathrm{CH} 19318$ & 0 & \multirow{4}{*}{ * } & & 1465 & 95 & 'charcoal' \\
\hline $\mathrm{CH} 19515$ & 0 & & & 1490 & 45 & 'charcoal' \\
\hline $\mathrm{CH} 19602$ & 0 & & & 1520 & 75 & carbonized tree branches \\
\hline EC-189 & 0 & & & 1580 & 70 & 'charcoal' \\
\hline \multicolumn{7}{|c|}{ tephra-fall deposit in flood-basin } \\
\hline Pozp.-57-594) & \multirow[t]{11}{*}{5} & \multirow[t]{11}{*}{ * } & UtC-14169 & 1535 & 44 & charred plant fragments \\
\hline PP1-32-33 & & & 54732 & 130 & 35 & charred plant fragments \\
\hline PP1-35-36 & & & 53748 & 715 & 30 & charred plant fragments \\
\hline PP1-47-48 & & & 53711 & 400 & 35 & charred plant fragments \\
\hline PP1-54-55 & & & 53734 & 870 & 35 & charred plant fragments \\
\hline PP1-56-57 & & & 54933 & 540 & 45 & charred plant fragments \\
\hline PP1-57-58 & & & 53735 & 345 & 35 & charred plant fragments \\
\hline PP1-60-61 & & & 53703 & 1200 & 75 & charred plant fragments \\
\hline PP1-62-63 & & & 53704 & 1090 & 45 & charred plant fragments \\
\hline PP1-70-71 & & & 53736 & 1025 & 35 & charred plant fragments \\
\hline PP1-71-72 & & & 54935 & 535 & 45 & charred plant fragments \\
\hline PP1-74-75 & 12.5 & * & 53705 & 1515 & 60 & charred plant fragments \\
\hline PP1-76-77 & 2.5 & & 53728 & 1670 & 55 & charred plant fragments \\
\hline PP1-77-78.5 & 0 & * & 53708 & 1535 & 40 & charred plant fragments \\
\hline PP1-78.5-80 & 0 & & 53706 & 1245 & 55 & charred plant fragments \\
\hline PP1-80-81 & -2.5 & & 54936 & 1870 & 60 & charred plant fragments \\
\hline PP1-81-82 & -7.5 & * & 53738 & 1530 & 35 & charred plant fragments \\
\hline PP1-89-90 & & & 53709 & 1850 & 45 & charred plant fragments \\
\hline PP1-96-97 & & & 53740 & 2025 & 35 & charred plant fragments \\
\hline PP1-129-130 & & & 53742 & 2390 & 35 & charred plant fragments \\
\hline PP1-169-170 & & & 53751 & 3220 & 40 & charred plant fragments \\
\hline \multicolumn{7}{|c|}{ turbidite lake Tuspan 5) } \\
\hline TuspanA-175 & & & & 1635 & 35 & terrestrial macroremains \\
\hline TuspanA-215 & & & & 1650 & 35 & terrestrial macroremains \\
\hline \multicolumn{7}{|c|}{ magnetite enrichment in beach ridge sands } \\
\hline 426-885L & & * & 58035 & 1665 & 35 & leaf fragments \\
\hline $426-255 \mathrm{~L}$ & & * & 58034 & 1690 & 40 & leaf fragments \\
\hline $480-290 \mathrm{~L}$ & 16 & * & 60871 & 1525 & 35 & leaf fragments \\
\hline 481-290L & 41 & * & 60873 & 1490 & 35 & leaf fragments \\
\hline 400-295L & & & 59694 & 1775 & 40 & leaf fragments \\
\hline $413-270 \mathrm{~L}$ & & * & 59438 & 1415 & 30 & leaf fragments \\
\hline $398-260 S$ & & * & 59437 & 1270 & 30 & squash seed \\
\hline 397-350L & & * & 58033 & 1390 & 35 & leaf fragments \\
\hline 396-270L & & * & 59757 & 1255 & 40 & leaf fragments \\
\hline 196-204L & & * & 55023 & 1235 & 30 & leaf fragments \\
\hline 193-171L & & * & 55022 & 1250 & 30 & leaf fragments \\
\hline 376-290L & & * & 59752 & 1075 & 40 & leaf fragments \\
\hline $378-280 \mathrm{~L}$ & & * & 59435 & 990 & 30 & leaf fragments \\
\hline 379-280L & & * & 58030 & 1015 & 35 & leaf fragments \\
\hline $381-225 \mathrm{~L}$ & & * & 59753 & 935 & 35 & leaf fragments \\
\hline $386-240 \mathrm{~L}$ & & * & 59755 & 820 & 40 & leaf fragments \\
\hline 386-610L & & & 59751 & 940 & 50 & leaf fragments \\
\hline 389-330L & & * & 58031 & 900 & 40 & leaf fragments \\
\hline 390-330L & & * & 59436 & 755 & 30 & leaf fragments \\
\hline 393-300L & & * & 58032 & 715 & 35 & leaf fragments \\
\hline
\end{tabular}

1. based on an organic sediment accumulation rate for the floodbasin cores of $2 \mathrm{~mm} / \mathrm{yr}$ and a beach ridge progradation rate of 3.3 m/yr; 2. samples with an asterisk were used in the calibrations (Fig. 2 and S4); 3. (Tilling et al., 1984, Espíndola et al., 2000 ); 4. (Nooren et al., 2009); 5. (Galop et al., 2004). 
Table S2. Compositions of tephra glass.

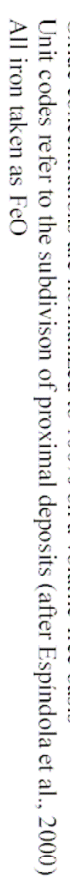

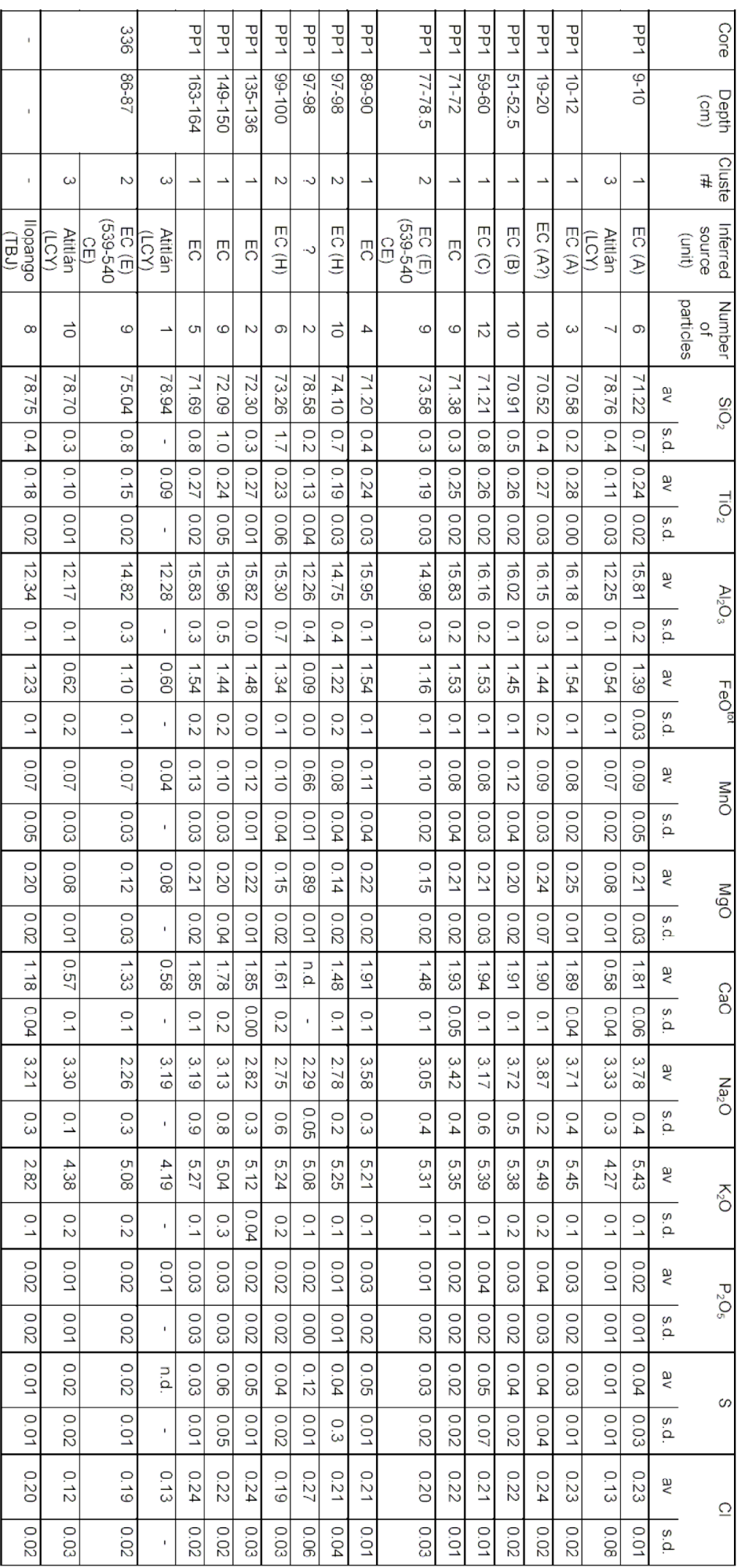




\section{REFERENCES CITED}

Andrews, B.J., Gardner, J.E., and Housh, T.B., 2008, Repeated recharge, assimilation, and hybridization in magmas erupted from El Chichón as recorded by plagioclase and amphibole phenocrysts: Journal of Volcanology and Geothermal Research, v. 175, p. 415-426.

Arce, J.L., Macías, J.L., Gardner, J.E., and Rangel, E., 2012, Reconstruction of the Sibinal Pumice, an andesitic Plinian eruption at Tacaná Volcanic Complex, Mexico-Guatemala: Journal of Volcanology and Geothermal Research, v. 217-218, p. 39-55.

Blockley, S.P.E., Pyne-O’Donnell, S.D.F., Lowe, J.J., Matthews, I.P., Stone, A., Pollard, A.M., Turney, C.S.M., and Molyneux, E.G., 2005, A new and less destructive laboratory procedure for the physical separation of distal glass tephra shards from sediments: Quaternary Science Reviews, v. 24(16-17), p. 1952-1960.

Bronk Ramsey, C., 2009, Bayesian analysis of Radiocarbon Dates: Radiocarbon, v. 51, p. 337360.

Cochemé, J.J., and Silva-Mora, L., 1983, Les éruptions de Mars-Avril 1982 du Volcan Chichonal: Bulletin of Volcanology, v. 46(1), p. 55-69.

Devine, J.D., Sigurdsson, H., and Davis, A.N., 1984. Estimates of Sulfur and Chlorine Yield to the Atmosphere from Volcanic Eruptions and Potential Climatic Effects: Journal of Geophysical Research, v. 89(B7), p. 6309-6325.

Drexler, J.W., Rose, W.I., Sparks, R.S.J., and Ledbetters, M.T., 1980, The Los Chocoyos Ash, Guatemala: A Major Stratigraphic Marker in Middle America and in Three Ocean Basins: Quarternary Research, v. 13, p. 327-345.

Dull, R.A., Southon, J.R., and Sheets, P.D., 2001, Volcanism, Ecology and Culture: A Reassessment of the Volcan Ilopango Tbj eruption in the Southern Maya Realm: Latin American Antiquity, v. 12, p. 25-44.

Espíndola, J.M., Macías, J.L., Tilling, R.I., and Sheridan, M.F., 2000, Volcanic history of El Chichón Volcano (Chiapas, Mexico) during the Holocene, and its impact on human activity: Bulletin of Volcanology, v. 62, p. 90-104.

Galop, D., Lemonnier, E., Carozza, J.-M., and Metailié, J.-P., 2004, Bosques, milpas, casas y aguadas de antaño, in Arnauld, C., et al., eds., La Joyanca (La Libertad, Guatemala): Antigua Ciudad Maya del Noroeste del Petén: Guatemala, Centro Francés de Estudios Mexicanos y Centroamericanos, Asociación Tikal, Centro de Investigaciones Regionales de Mesoamérica, p. 55-71.

Jones, D.A., Layer, P.W., and Newberry, R.J., 2008, A 3100-year history of argon isotopic and compositional variation at El Chichón volcano: Journal of Volcanology and Geothermal Research, v. 175, p. 427-443.

Kutterolf, S., Freundt, A., Peréz, W., Mörz, T., Schacht, U., Wehrmann, H., and Schmincke, H.U., 2008, Pacific offshore record of plinian arc volcanism in Central America: 1. Along-arc correlations: Geochemistry, Geophysics, Geosystems, v. 9:Q02S01.

Luhr, J.F., Carmichael, S.E., and Varekamp, J.C., 1984, The 1982 eruptions of El Chichón Volcano, Chiapas, Mexico: mineralogy and petrology of the anhydrite-bearing pumices: Journal of Volcanology and Geothermal Research, v. 23 (1-2), p. 69-108.

Macías, J.L., Arce, J.L., Mora, J.C., Espíndola, J.M., and Saucedo, R., 2003, A 550-year-old Plinian eruption at El Chichón Volcano, Chiapas, Mexico: Explosive volcanism linked to reheating of the magma reservoir: Journal of Geophysical Research, v. 108 (B12):2569. 
Mook, W.G., and Van der Plicht, J., 1999, Reporting 14C activities and concentrations: Radiocarbon, v. 41, p. 227-239.

Nooren, C.A.M., Hoek, W.Z., Tebbens, L.A., and Martin Del Pozzo, A.L., 2009, Tephrochronological evidence for the late Holocene eruption history of El Chichón Volcano, Mexico: Geofisica Internacional, v. 48(1), p. 97-112.

Ortega-Guerrero, B., and Newton, A.J., 1998, Geochemical characterization of late PleistoceneHolocene tephra layers from the Basin of Mexico, central Mexico: Quaternary Research, v. 50, p. 90-106.

Palais, J.M., Germani, M.S., and Zielinski, G.A., 1992, Inter-Hemispheric transport of volcanic ash from a 1259 A.D. volcanic eruption to the Greenland and Antarctic ice sheets: Geophysical Research Letters, v. 19, p. 801-804.

Reimer, P.J., et al., 2013, IntCal13 and Marine13 Radiocarbon age Calibration Curves 0 - 50,000 years cal BP: Radiocarbon, v. 55, p.1869-1887.

Sigl, M., et al., 2015, Timing and climate forcing of volcanic eruptions for the past 2,500 years: Nature, v. 523, p. 543-549.

Tilling, R.I., Rubin, M., Sigurdsson, H., Carey, S., Duffield, W.A., and Rose, W.I., 1984, Holocene Eruptive Activity of El Chichón Volcano, Chiapas, Mexico: Science, v. 224(4650), p.747-749.

Van der Plicht, J., Wijma, S., Aerts, A.T., Pertuisot, M.H., and Meijer, H.A.J., 2000, The Groningen AMS facility: status report. Nuclear Instruments and Methods, v. B172, p. 58-65. 